\title{
Pengaruh Harga dan Fasilitas terhadap Minat Sewa Kost yang Berdampak pada Prestasi Belajar Mahasiswa di Yogyakarta
}

\section{The Influence of Prices and Facilities Towards Rental Interests that Impact on Student Achievements in Yogyakarta}

\author{
Denok Sunarsi, Akhmar Barsah, H. Hastono \& Irfan Rizka Akbar
}

Universitas Pamulang, Banten, Indonesia

Diterima: 01 Oktober 2020 ; Direview : 03 Oktober 2020 ; Disetujui : 18 Oktober 2020

*Coresponding Email : denoksunarsi@unpam.ac.id1, dosen01578@unpam.ac.id2, dosen00340@unpam.ac.id3, dosen02461@unpam.ac.id4

\section{Abstrak}

Penelitian ini bertujuan untuk mengetahui pengaruh harga dan fasilitas terhadap minat sewa kost yang berdampak pada prestasi belajar mahasiswa di Yogyakarta. Metode yang digunakan adalah explanatory research dengan teknik analisis menggunakan analisis statistik dengan pengujian regresi, korelasi, determinasi dan uji hipotesis. Hasil penelitian ini harga berpengaruh signifikan terhadap minat sewa sebesar 37,0\%, uji hipotesis diperoleh t hitung $>t$ tabel atau $(7,590>1,984)$. Fasilitas berpengaruh signifikan terhadap minat sewa sebesar 48,9\%, uji hipotesis diperoleh $t$ hitung $>\mathrm{t}$ tabel atau $(9,677>$ 1,984). Harga dan fasilitas secara simultan berpengaruh signifikan terhadap minat sewa dengan persamaan regresi $Y=9,005+0,274 X 1+0,514 X 2$ dan kontribusi pengaruh sebesar 55,5\%, uji hipotesis diperoleh $\mathrm{F}$ hitung $>\mathrm{F}$ tabel atau $(60,568>2,699)$.Minat sewa berpengaruh signifikan terhadap prestasi belajar mahasiswa sebesar 39,8\%, uji hipotesis diperoleh $t$ hitung $>t$ tabel atau $(8,051>1,984)$

Kata Kunci: Harga, Fasilitas, Minat Sewa, Prestasi Belajar

\section{Abstract}

This study aims to determine the effect of price and facilities on boarding rent interest which has an impact on student achievement in Yogyakarta. The method used is explanatory research with analysis techniques using statistical analysis with regression testing, correlation, determination and hypothesis testing. The results of this study, the price has a significant effect on interest in lease by $37.0 \%$, the hypothesis test obtained $t$ count $>t$ table or (7.590> 1.984). Facilities have a significant effect on rental interest by 48.9\%, hypothesis testing is obtained t count> t table or (9.677> 1.984). Price and facilities simultaneously have a significant effect on rental interest with the regression equation $Y=9.005+0.274 X 1+0.514 X 2$ and the contribution of the effect is $55.5 \%$, the hypothesis test obtained $F$ count $>F$ table or $(60.568>2,699)$. Rental interest has a significant effect on student achievement by 39.8\%, hypothesis testing is obtained $t$ count $>t$ table or $(8,051>1,984)$

Keywords: Price, Facilities, Rental Interest, Learning Achievement

How to Cite: Sunarsi, D. Barsah, A. Hastono, H \& Akbar, I.R. (2020). Pengaruh Harga dan Fasilitas Terhadap Minat Sewa Kost yang Berdampak Pada Prestasi Belajar Mahasiswa di Yogyakarta. Journal of Education, Humaniora and Social Sciences (JEHSS). 3(2): 601-609. 


\section{PENDAHULUAN}

Hidup jauh dari keluarga membuat penghuni kost mau tak mau harus mandiri. Suasana kost sangat menentukan betah tidaknya sang penghuni. Seiring berkembangnya zaman, model dan jenis rumah kost semakin beragam. Dulu rumah kost identik dengan kesederhanaan dengan fasilitas seadanya biasanya dibagi per kamar tapi kini kost bahkan telah menggambarkan status sosial penghuninya.

Sejak lama Jogja memang dikenal sebagai kota pelajar, di kota ini Anda bisa menuntut ilmu dari berbagai universitas terkemuka sebut saja seperti Universitas Gajah Mada (UGM), Universitas Negeri Yogyakarta (UNY), Universitas Ahmad Dahlan, Universitas Islam Indonesia dan lain-lain. Karena menjamurnya perguruan tinggi di Jogja, tak heran kondisi ini pun dimanfaatkan oleh para pengembang untuk membangun apartemen dengan menyasar segmen mahasiswa, tidak hanya itu, bisnis usaha kostsan pun di sana sekarang dianggap sebagai salah satu peluang usaha yang sangat menjanjikan.

Salah satunya adalah Universitas Teknologi Yogyakarta berdiri pada tanggal 23 oktober 2002 di Kota Yogyakarta. Pendirian Universitas Teknologi Yogyakarta ditandai dengan turunnya sk penggabungan dari menteri pendidikan nasional ri bernomor 237/d/0/2002 tertanggal 23 oktober 2002. Universitas Teknologi Yogyakarta didirikan oleh para pengurus yayasan "dharma bhakti iptek" yang telah terbukti memiliki komitmen tinggi memajukan kehidupan anak bangsa melalui lembaga pendidikan yang di kelola sebelumnya

Yogyakarta adalah Daerah Istimewa yang terletak di tengah pulau Jawa yang terkenal dengan kebudayaan,wisata,dan banyaknya orang yang datang ke Yogya dengan tujuan bukan hanya untuk berlibur tetapi untuk belajar atau menuntut ilmu. Yogyakarta terkenal karena banyaknya universitas dan sekolah yang sampai saat ini masih terus menjadi salah satu tujuan pelajar dan mahasiswa Indonesia bahkan luar negeri untuk belajar atau melanjutkan pendidikan. Kota Yogyakarta dijuluki sebagai kota pelajar karena sebagian besar penduduknya adalah pelajar atau mahasiswa yang datang dari berbagai daerah atau pulau dari sabang sampai merauke.

Banyak sekali alasan, jika dicari tahu dan dirunut, kenapa seseorang ingin lebih tinggal sendiri di kost ketimbang terus bersama dengan orangtua mereka. Yang paling umum adalah soal kebebasan menentukan pendapat dan keinginan ketika berada di rumah kost sendiri. Karena seringkali ruang gerak dibatasi kalau terus - terusan dekat dan satu atap dengan orang tua

Dengan konsep moderinitas, kost bisa lebih mewah dari rumah paling mewah di desa sekalipun. Pengaruh hedonisme dan tuntutan globalisasi yang menyerang semua kalangan, termasuk mahasiswa telah merubah semangat dan idealisme tersebut. Dalam memilih kost mahasiswa sekarang tidak hanya menuntut adanya listrik dan air PAM, tetapi juga fasilitas lainnya semisal layanan internet (hot spot). Sejak dahulu kala, mencari kost-kostan bukan perkara gampang. harus benar-benar pas dan bisa membuat nyaman, karena akan dijadikan tempat berpulang melepas kejenuhan, dewasa ini, kost-kostan atau pemondokan telah berubah fungsi utamanya sebagai tempat tinggal menjadi sebuah industri kost yang lebih berorientasi pada materi saja sehingga transformasi akan nilai-nilai yang ada dalam masyarakat cenderung terabaikan sehingga tidak menutup kemungkinan munculnya suatu perilaku menyimpang atau pelanggaran yang dilakukan oleh anak indekost, misalnya sering terjadi pencurian seks bebas dan narkoba di kost

Rata-rata kost eksklusif di wilayah Sleman biasanya menjual beberapa keunggulan yang sekaligus menjadi pertimbangan orang tua yang anaknya baru pertama tinggal di kostan yaitu lokasi, lingkungan dan penghuni. Semakin dekat dengan kampus, harganya akan semakin mahal. 
Vol 3, No. 2, Desember 2020: 601 -609

Tabel 1. Daftar Rumah Kost Yogyakarta

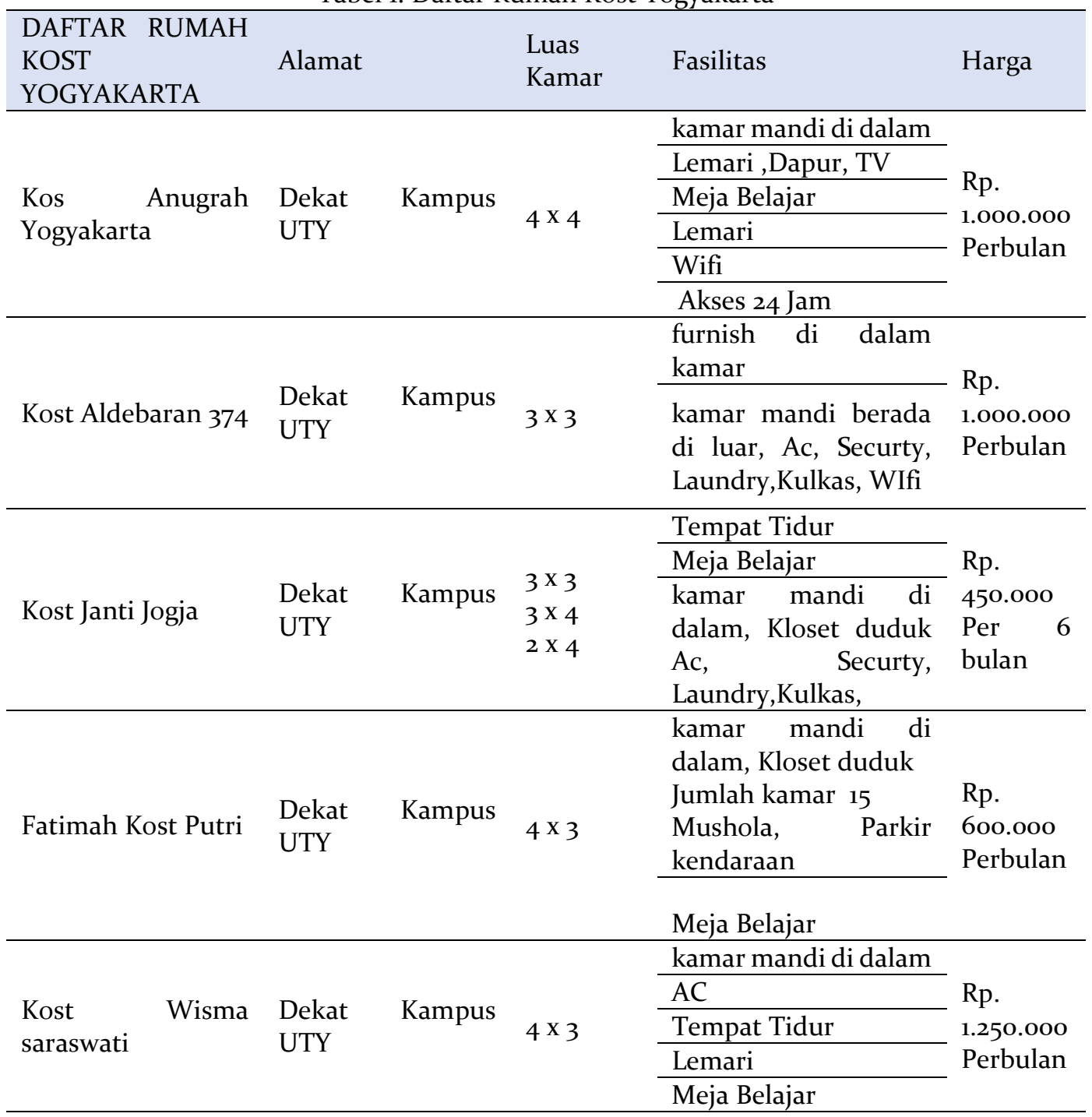

http://www.infokostan.com/info-kost-jogja/, $\quad$ https://mamikos.com/kost/kost-putri-dekat-uty-jogjamurah,

Hingga hari ini kota Yogyakarta masih menjadi tujuan utama sebagai tempat mendapatkan pendidikan yang bermutu di Indonesia. Sebagai kota pelajar, di Yogyakarta setiap tahun selalu dibanjiri oleh mahasiswa baru, kebanyakan mahasiswa baru di Yogyakarta adalah mayoritas perantau yang masih awam untuk mencari sebuah rumah kost sebagai rumah tinggal sementara di Yogyakarta, maka mencari kost menjadi kendala tersendiri.

Kos adalah hunian yang menyediakan kamar untuk tinggal, lengkap dengan perabot standar tempat kost: tempat tidur dan lemari. Tempat tinggal kost-kostan biasanya terdapat dalam areal yang dekat dengan kampus (Setyawan, 2018). Pemiliknya biasanya merupakan penduduk setempat ataupun pemilik modal yang besar. Kost-kostan untuk mahasiswa biasanya terdiri dari satu kamar dan di dalamnya terdapat satu tempat tidur, satu meja belajar dan satu lemari. Dan biasanya menggunakan kamar mandi dan dapur secara kolektif. Pada saat sekarang ini pembangunan kost-kostan semakin berkembang dan fasilitas yang diberikan juga semakin eksklusif. Hal ini terlihat dalam penyediaan AC, kamar mandi dalam, ruang tamu, dan lainlainnya. Sistem pembayaran kost-kostan didasarkan pada jangka waktu sebulan, terkadang bisa tiga bulan langsung. Pembayaran untuk jangka waktu yang panjang biasanya akan diberikan potongan oleh pemilik kost-kostan.

Fasilitas yang ditawarkan oleh kost-kostan juga menjadi bahan pertimbangan mahasiswa dalam memilih kost-kostan. Karena itu pemilik kost ada yang menawarkan 象 http://mahesainstitute.web.id/ojs2/index.php/jehss

mahesainstitut@gmail.com

603 
fasilitas-fasilitas seperti: 1) Bentuk dan bahan bangunan. 2) Kamar ber AC. 3) Kamar mandi pribadi. 4) Isi kamar lengkap. 5) Kamar yang luas. 6) Tempat parkir. 7) TV. 8) Mesin cuci. 9) Jasajasa tambahan. 10) Wifi.

Bagi mahasiswa yang tergolong mampu, mereka cenderung mengutamakan fasilitas dalam memilih kost-kostan. Harga menjadi faktor pertimbangan terakhir. Mengenai aksesibilitas, golongan mahasiswa ini cenderung tidak terlalu mempermasalahkannya karena mereka memiliki sarana, misalnya alat transportasi. Bagi mahasiswa yang memiliki kemampuan ekonomi sedang, sebagian memilih tempat tinggal yang dekat dengan kampus dimana biaya untuk transportasi bisa lebih ditekan. Sebagian lagi memilih yang lebih jauh dengan harga sewa yang lebih rendah. Mereka memilihnya karena mereka memiliki sarana transportasi pribadi misalnya sepeda motor untuk mencapai kampus. Bagi mahasiswa yang tergolong kurang mampu, mereka memilih tempat tinggal yang murah dan dekat dengan kampus agar bisa dicapai dengan jalan kaki atau biaya seminim mungkin. Fasilitas menjadi faktor pertimbangan terakhir bagi mereka (Kurniawan, 2015; Hastono, 2020; Lukiastuti, 2020; Sunarto, 2009; Amilia, dan Iriyani, 2019; Rahmawati dan Hastuti, 2017).

Hal selanjutnya yang dijual adalah lingkungan. Dekat dengan makanan, fotocopy, rumah sakit, dan lingkungan kampus menjadi nilai jual tersendiri. Orang tua yang baru pertama melepas anaknya tinggal jauh pasti berfikir bahwa lingkungan dekat kampus akan lebih tidak neko-neko. Anak akan berada di atmosfer pendidikan, belajar semakin nyaman, masa depan semakin tinggi Fenomena kost dengan harga yang mahal sepertinya didorong oleh perubahan paradigma tentang anak kost. Anak kost yang dulu dipandang sebagai anak ngirit atau anak nggak ada duit (karena memang kita jauh dari orang tua, sekolah - bukan bekerja) sekarang dipandang menjadi anak mandiri.

Lingkungan sangat mempengaruhi proses belajar untuk pengembangan pribadi mahasiswa, di mana proses belajar itu akan dapat meningkatkan kepribadian dan berupaya untuk memperoleh hal-hal baru yang dapat memperbaiki dan meningkatkan kontradiksi kontradiksi dalam hidupnya (Wijoyo \& Indrawan, 2020).

Prestasi belajar merupakan dambaan bagi setiap mahasiswa dan juga orangtua mereka. Prestasi belajar yang baik diperoleh dengan proses belajar yang baik juga (Hulu \& Irna, 2013; Tarigan, et al.,2015; Sitanggang \& Nini, 2014). Prestasi itu tidak mungkin dicapai atau dihasilkan oleh seseorang selama ia tidak melakukan kegiatan dengan sungguh sungguh (Rahmayati \& Zulkarnain, 2013; Minauli \& Imelda, 2011). Dalam kenyataannya untuk mendapatkan prestasi tidak semudah membalikkan telapak tangan, tetapi harus penuh perjuangan dan berbagai rintangan dan hambatan yang harus dihadapi untuk mencapainya (Wijoyo, 2020).

Berdasarkan fenomena yang peneliti temukan pada observasi awal maka peneliti tertarik untuk mengalisa dengan harapan mampu memberikan kontribusi pada pemerintah setempat melalui kegiatan penelitian dengan tema "Analisis Pengaruh Harga dan Fasilitas Terhadap Minat Sewa Kost Yang Berdampak Pada Prestasi Belajar Mahasiswa di Yogyakarta".

\section{METODE PENELITIAN}

Populasi dalam penelitian ini berjumlah 100 responden yaitu mahasiswa yang menyewa kost di wilayah Yogyakarta. Sampel dalam penelitian ini berjumlah 100 responden yaitu mahasiswa yang menyewa kost di wilayah Yogyakarta. Jenis penelitian yang dipakai adalah asosiatif, dimana tujuannya adalah untuk mengetahui pengaruh antara variabel bebas terhadap variabel terikat baik parsial maupun simultan. Dalam menganalisis data digunakan uji instrumen, uji asumsi klasik, regresi, koefisien determinasi dan uji hipotesis.

\section{HASIL DAN PEMBAHASAN Analisis Deskriptif}

Pada pengujian ini digunakan untuk mengetahui skor minimum dan maksimum, mean score dan standar deviasi dari masing-masing variabel. Adapun hasilnya sebagai berikut: 
Vol 3, No. 2, Desember 2020: 601 -609

Tabel 2. Hasil Analisis Descriptive Statistics

Descriptive Statistics

\begin{tabular}{llllll} 
& $\mathrm{N}$ & Minimum & Maximum & Mean & Std. Deviation \\
\hline Harga $\left(\mathrm{X}_{1}\right)$ & 100 & 32 & 48 & 38.49 & 4.135 \\
\hline Fasilitas $\left(\mathrm{X}_{2}\right)$ & 100 & 30 & 45 & 38.42 & 3.680 \\
\hline Minat Sewa $(\mathrm{Y})$ & 100 & 32 & 46 & 39.30 & 3.622 \\
\hline Prestasi Belajar $(\mathrm{Z})$ & 100 & 31 & 46 & 39.28 & 3.565 \\
\hline Valid N (listwise) & 100 & & & & \\
\hline
\end{tabular}

Harga diperoleh varians minimum sebesar 32 dan varians maximum 48 dengan mean score sebesar 38,49 dengan standar deviasi 4,135. Fasilitas diperoleh varians minimum sebesar 30 dan varians maximum 45 dengan mean score sebesar 38,42 dengan standar deviasi 3,680. Minat sewa diperoleh varians minimum sebesar 32 dan varians maximum 46 dengan mean score sebesar 39,30 dengan standar deviasi 3,622. Preastasi belajar mahasiswa diperoleh varians minimum sebesar 31 dan varians maximum 46 dengan mean score sebesar 39,28 dengan standar deviasi 3,565.

\section{Analisis Verifikatif.}

Pada analisis ini dimaksudkan untuk mengetahui pengaruh variabel independen terhadap variabel dependen. Adapun hasil pengujian sebagai berikut:

\section{a. Analisis Regresi Linier Berganda}

Uji regresi ini dimaksudkan untuk mengetahui perubahan variabel dependen jika variabel independen mengalami perubahan. Adapun hasil pengujiannya sebagai berikut:

Tabel 3. Hasil Pengujian Regresi Linier Berganda Coefficients $^{\mathrm{a}}$

Unstandardized Coefficients Standardized Coefficients

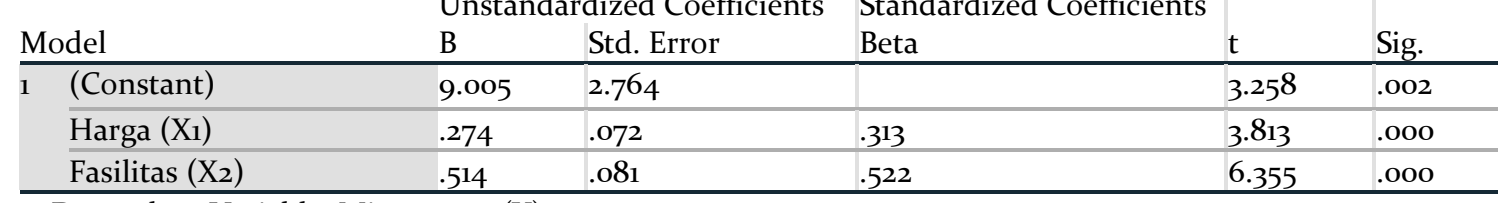

a. Dependent Variable: Minat sewa (Y)

Berdasarkan hasil pengujian pada tabel di atas, diperoleh persamaan regresi $\mathrm{Y}=9,005+$ 0,274X1 + 0,514X2. Dari persamaan tersebut dijelaskan sebagai berikut:

1) Konstanta sebesar 9,005 diartikan jika harga dan fasilitas tidak ada, maka telah terdapat nilai minat sewa sebesar 9,005 point.

2) Koefisien regresi harga sebesar 0,274, angka ini positif artinya setiap ada peningkatan harga sebesar 0,274 maka minat sewa juga akan mengalami peningkatan sebesar 0,274 point.

3) Koefisien regresi fasilitas sebesar 0,514, angka ini positif artinya setiap ada peningkatan fasilitas sebesar 0,514 maka minat sewa juga akan mengalami peningkatan sebesar 0,514 point.

4) Koefisien regresi minat sewa sebesar 0,515, angka ini positif artinya setiap ada peningkatan minat sewa sebesar 0,515 maka prestasi belajar mahasiswa juga akan mengalami peningkatan sebesar 0,515 point.

\section{b. Analisis Koefisien Korelasi}

Analisis koefisien korelasi dimaksudkan untuk mengetahui tingkt kekuatan hubungan dari variabel independen terhadap variabel dependen baik secara parsial maupun simultan. Adapun hasil pengujian sebagai berikut: 
Denok Sunarsi, Akhmar Barsah, H. Hastono, \& Irfan Rizka Akbar, Pengaruh Harga dan Fasilitas Terhadap

Tabel 4. Hasil Pengujian Koefisien Korelasi Harga Terhadap Minat sewa. Correlations ${ }^{\mathrm{b}}$

\begin{tabular}{llll} 
& & Harga $\left(\mathrm{X}_{1}\right)$ & Minat sewa $(\mathrm{Y})$ \\
\hline Harga $\left(\mathrm{X}_{1}\right)$ & Pearson Correlation & 1 & $.608^{* *}$ \\
\cline { 2 - 4 } & Sig. (2-tailed) & .000 \\
\hline Minat sewa $(\mathrm{Y})$ & Pearson Correlation & $.608^{* *}$ & 1 \\
\cline { 2 - 4 } & Sig. (2-tailed) & .000 & \\
\hline
\end{tabular}

Berdasarkan hasil pengujian diperoleh nilai korelasi sebesar 0,608 artinya harga memiliki hubungan yang kuat terhadap minat sewa.

Tabel 5. Hasil Pengujian Koefisien Korelasi Fasilitas Terhadap Minat sewa. Correlations $^{\mathrm{b}}$

\begin{tabular}{llll} 
& & Fasilitas $\left(\mathrm{X}_{2}\right)$ & Minat sewa $(\mathrm{Y})$ \\
\hline Fasilitas (X2) & Pearson Correlation & 1 & $.699^{* *}$ \\
\cline { 2 - 4 } & Sig. (2-tailed) & & .000 \\
\hline Minat sewa (Y) & Pearson Correlation & $.699^{* *}$ & 1 \\
\cline { 2 - 4 } & Sig. (2-tailed) & .000 & \\
\hline
\end{tabular}

Berdasarkan hasil pengujian diperoleh nilai korelasi sebesar 0,699 artinya fasilitas memiliki hubungan yang kuat terhadap minat sewa.

Tabel 6. Hasil Pengujian Koefisien Korelasi Harga dan Fasilitas secara simultan Terhadap Minat sewa. Model Summary

\begin{tabular}{|c|c|c|c|c|}
\hline Model & $\mathrm{R}$ & R Square & $\begin{array}{l}\text { Adjusted } \\
\text { Square }\end{array}$ & ${ }^{\mathrm{R}}$ Std. Error of the Estimate \\
\hline 1 & $.745^{\mathrm{a}}$ & .555 & .546 & 2.440 \\
\hline
\end{tabular}

a. Predictors: (Constant), Fasilitas ( $\left.\mathrm{X}_{2}\right)$, Harga $\left(\mathrm{X}_{1}\right)$

Berdasarkan hasil pengujian diperoleh nilai korelasi sebesar 0,745 artinya harga dan fasilitas secara simultan memiliki hubungan yang kuat terhadap minat sewa.

Tabel 7. Hasil Pengujian Koefisien Korelasi Minat Sewa Terhadap Prestasi Belajar Mahasiswa. Correlations $^{\mathrm{b}}$

\begin{tabular}{llll} 
& & Fasilitas $\left(\mathrm{X}_{2}\right)$ & Minat sewa $(\mathrm{Y})$ \\
\hline Minat Sewa (Y) & Pearson Correlation & 1 & $.631^{* *}$ \\
\cline { 2 - 4 } & Sig. (2-tailed) & .000 \\
\hline Prestasi Belajar (Z) & Pearson Correlation & $.631^{* *}$ & 1 \\
\cline { 2 - 4 } & Sig. (2-tailed) & .000 & \\
\hline
\end{tabular}

Berdasarkan hasil pengujian diperoleh nilai korelasi sebesar 0,631 artinya minat sewa memiliki hubungan yang kuat terhadap prestasi belajar.

\section{c. Analisis Koefisien Determinasi}

Analisis koefisien determinasi dimaksudkan untuk mengetahui besarnya persentase pengaruh dari variabel independen terhadap variabel dependen baik secara parsial maupun simultan. Adapun hasil pengujian sebagai berikut:

Tabel 8. Hasil Pengujian Koefisien Determinasi Harga Terhadap Minat sewa. Model Summary

\begin{tabular}{llllll} 
Model & $\mathrm{R}$ & R Square & $\begin{array}{l}\text { Adjusted } \\
\text { Square }\end{array}$ & $\begin{array}{c}\text { RStd. Error of the } \\
\text { Estimate }\end{array}$ \\
\hline 1 & $.608^{\mathrm{a}}$ & .370 & .364 & 2.889 \\
\hline
\end{tabular}

a. Predictors: (Constant), Harga (X1)

Berdasarkan hasil pengujian diperoleh nilai determinasi sebesar 0,370 artinya harga memiliki kontribusi pengaruh sebesar 37,0\% terhadap minat sewa. 
Tabel 9. Hasil Pengujian Koefisien Determinasi Fasilitas Terhadap Minat sewa.

$$
\text { Model Summary }
$$

\begin{tabular}{lllll} 
Model & R & R Square & Adjusted R Square & Std. Error of the Estimate \\
\hline 1 & $.699^{\mathrm{a}}$ & .489 & .483 & 2.603 \\
\hline
\end{tabular}

a. Predictors: (Constant), Fasilitas (X2)

Berdasarkan hasil pengujian diperoleh nilai determinasi sebesar 0,489 artinya fasilitas memiliki kontribusi pengaruh sebesar 48,9\% terhadap minat sewa.

Tabel 10. Hasil Pengujian Koefisien Determinasi Harga dan Fasilitas Terhadap Minat sewa.

Model Summary

\begin{tabular}{|c|c|c|c|c|}
\hline Model & $\mathrm{R}$ & R Square & $\begin{array}{l}\text { Adjusted } \\
\text { Square }\end{array}$ & $\begin{array}{l}\text { RStd. Error of the } \\
\text { Estimate }\end{array}$ \\
\hline 1 & $.745^{\mathrm{a}}$ & .555 & .546 & 2.440 \\
\hline
\end{tabular}

a. Predictors: (Constant), Fasilitas (X2), Harga $\left(\mathrm{X}_{1}\right)$

Berdasarkan hasil pengujian diperoleh nilai determinasi sebesar 0,555 artinya harga dan fasilitas secara simultan memiliki kontribusi pengaruh sebesar 55,5\% terhadap minat sewa, sedangkan sisanya sebesar 44,5\% dipengaruhi faktor lain.

Tabel 11. Hasil Pengujian Koefisien Determinasi Minat Sewa Terhadap Prestasi Belajar. Model Summary

\begin{tabular}{ll|lll} 
Model & R & R Square & $\begin{array}{l}\text { Adjusted } \\
\text { Square }\end{array}$ & R \\
\hline $\mathbf{1}$ & $.631^{\mathrm{a}}$ & .398 & .392 & 2.780 \\
\hline
\end{tabular}

a. Predictors: (Constant), Minat Sewa (Y)

Berdasarkan hasil pengujian diperoleh nilai determinasi sebesar 0,398 artinya minat sewa memiliki kontribusi pengaruh sebesar 39,8\% terhadap prestasi belajar.

\section{d. Uji Hipotesis}

Uji hipotesis Parsial (Uji t) diterima.

Pengujian hipotesis dengan uji t digunakan untuk mengetahui hipotesis parsial mana yang

Hipotesis pertama: Terdapat pengaruh yang signifikan antara harga terhadap minat sewa.

Tabel 12. Hasil Uji Hipotesis Harga Terhadap Minat sewa.

Coefficients ${ }^{\mathrm{a}}$

\begin{tabular}{|c|c|c|c|c|c|}
\hline \multirow[b]{2}{*}{ Model } & \multicolumn{2}{|c|}{ Unstandardized Coefficients } & \multirow{2}{*}{$\begin{array}{l}\text { Standardized Coefficients } \\
\text { Beta }\end{array}$} & \multirow[b]{2}{*}{$\mathrm{t}$} & \multirow[b]{2}{*}{ Sig. } \\
\hline & $\mathrm{B}$ & Std. Error & & & \\
\hline $\begin{array}{ll}1 & \text { (Constant) }\end{array}$ & 18.786 & 2.718 & & 6.911 & .000 \\
\hline Harga $\left(\mathrm{X}_{1}\right)$ & .533 & .070 & .608 & 7.590 & .000 \\
\hline
\end{tabular}

a. Dependent Variable: Minat sewa (Y)

Berdasarkan hasil pengujian pada tabel di atas, diperoleh nilai t hitung $>\mathrm{t}$ tabel atau $(7,590$ $>1,984$ ), dengan demikian hipotesis pertama yang diajukan bahwa terdapat pengaruh yang signifikan atara harga terhadap minat sewa diterima.

Tabel 13. Hasil Uji Hipotesis Fasilitas Terhadap Minat sewa.

$$
\text { Coefficients }^{\mathrm{a}}
$$

Unstandardized Coefficients Standardized Coefficients

\begin{tabular}{llll|lll}
\multicolumn{2}{l}{ Model } & B & Std. Error & Beta & t & Sig. \\
\hline 1 & (Constant) & 12.860 & 2.744 & & 4.686 & .000 \\
\cline { 2 - 7 } & Fasilitas $\left(\mathrm{X}_{2}\right)$ & .688 & .071 & .699 & 9.677 & .000 \\
\hline
\end{tabular}

a. Dependent Variable: Minat sewa (Y)

Berdasarkan hasil pengujian pada tabel di atas, diperoleh nilai $t$ hitung $>\mathrm{t}$ tabel atau $(9,677$ $>1,984)$, dengan demikian hipotesis kedua yang diajukan bahwa terdapat pengaruh yang signifikan atara fasilitas terhadap minat sewa diterima. 
Denok Sunarsi, Akhmar Barsah, H. Hastono, \& Irfan Rizka Akbar, Pengaruh Harga dan Fasilitas

Terhadap

Tabel 14. Hasil Uji Hipotesis Minat Sewa Terhadap Prestasi Belajar.

Coefficients $^{\mathrm{a}}$

\begin{tabular}{|c|c|c|c|c|c|c|}
\hline \multirow{3}{*}{\multicolumn{2}{|c|}{ Model }} & \multirow{2}{*}{\multicolumn{2}{|c|}{ Unstandardized Coefficients }} & \multirow{3}{*}{$\begin{array}{l}\text { Standardized Coefficients } \\
\text { Beta }\end{array}$} & \multirow[b]{3}{*}{$\mathrm{t}$} & \multirow[b]{3}{*}{ Sig. } \\
\hline & & & & & & \\
\hline & & B & Std. Error & & & \\
\hline \multirow[t]{2}{*}{1} & (Constant) & 14.877 & 3.044 & & 4.888 & .000 \\
\hline & Minat Sewa (Y) & .621 & .077 & .631 & 8.051 & .000 \\
\hline
\end{tabular}

a. Dependent Variable: Prestasi Belajar (Z)

Berdasarkan hasil pengujian pada tabel di atas, diperoleh nilai $t$ hitung $>t$ tabel atau $(8,051$ $>1,984)$, dengan demikian hipotesis keempat yang diajukan bahwa terdapat pengaruh yang signifikan atara minat sewa terhadap prestasi belajar diterima.

\section{Uji Hipotesis Simultan (Uji F)}

Pengujian hipotesis dengan uji F digunakan untuk mengetahui hipotesis simultan yang mana yang diterima.

Hipotesis ketiga Terdapat pengaruh yang signifikan antara harga dan fasilitas terhadap minat sewa.

Tabel 15. Hasil Uji Hipotesis Harga dan Fasilitas Terhadap Minat sewa.

$$
\text { ANOVA }^{a}
$$

\begin{tabular}{llllllll} 
Model & & Sum of Squares & df & Mean Square & F & Sig. \\
\hline 1 & Regression & 721.364 & 2 & 360.682 & 60.568 & .000 $^{\mathrm{b}}$ \\
\cline { 2 - 6 } & Residual & 577.636 & 97 & 5.955 & & \\
\cline { 2 - 4 } & $\mathbf{1 2 9 9 . 0 0 0}$ & 99 & & & \\
\hline
\end{tabular}

Berdasarkan hasil pengujian pada tabel di atas, diperoleh nilai $\mathrm{F}$ hitung $>\mathrm{F}$ tabel atau $(60,568$ $>2,699$ ), dengan demikian hipotesis ketiga yang diajukan bahwa terdapat pengaruh yang signifikan atara harga dan fasilitas terhadap minat sewa diterima.

\section{Pengaruh Harga Terhadap Minat Sewa}

Harga berpengaruh signifikan terhadap minat sewa dengan korelasi sebesar 0,608 atau memiliki hubungan yang kuat dengan kontribusi pengaruh sebesar 37,0\%. Pengujian hipotesis diperoleh nilai $t$ hitung $>t$ tabel atau $(7,590>1,984)$. Dengan demikian hipotesis pertama yang diajukan bahwa terdapat berpengaruh signifikan antara harga terhadap minat sewa diterima.

\section{Pengaruh Fasilitas Terhadap Minat Sewa}

Fasilitas berpengaruh signifikan terhadap minat sewa dengan korelasi sebesar 0,699 atau memiliki hubungan yang kuat dengan kontribusi pengaruh sebesar 48,9\%. Pengujian hipotesis diperoleh nilai $t$ hitung $>\mathrm{t}$ tabel atau $(9,677>1,984)$. Dengan demikian hipotesis kedua yang diajukan bahwa terdapat berpengaruh signifikan antara fasilitas terhadap minat sewa diterima.

\section{Pengaruh Harga dan Fasilitas Terhadap Minat Sewa}

Harga dan fasilitas berpengaruh signifikan terhadap minat sewa dengan diperoleh persamaan regresi $Y=9,005+0,274 X 1+0,514 X 2$, nilai korelasi sebesar 0,745 atau memiliki hubungan yang kuat dengan kontribusi pengaruh sebesar 55,5\% sedangkan sisanya sebesar $44,5 \%$ dipengaruhi faktor lain. Pengujian hipotesis diperoleh nilai $\mathrm{F}$ hitung $>\mathrm{F}$ tabel atau $(60,568$ $>2,699$ ). Dengan demikian hipotesis ketiga yang diajukan bahwa terdapat berpengaruh signifikan antara harga dan fasilitas terhadap minat sewa diterima.

\section{Pengaruh Minat Sewa Terhadap Prestasi Belajar}

Minat sewa berpengaruh signifikan terhadap prestasi belajar dengan korelasi sebesar 0,631 atau memiliki hubungan yang kuat dengan kontribusi pengaruh sebesar 39,8\%. Pengujian hipotesis diperoleh nilai $t$ hitung $>t$ tabel atau $(8,051>1,984)$. Dengan demikian hipotesis keempat yang diajukan bahwa terdapat berpengaruh signifikan antara minat sewa terhadap prestasi belajar diterima.

\section{SIMPULAN}

Harga berpengaruh signifikan terhadap minat sewa dengan kontribusi pengaruh sebesar $37,0 \%$. Uji hipotesis diperoleh nilai t hitung $>t$ tabel atau $(7,590>1,984)$. Fasilitas berpengaruh 
signifikan terhadap minat sewa dengan kontribusi pengaruh sebesar 48,9\%. Uji hipotesis diperoleh nilai t hitung $>t$ tabel atau $(9,677>1,984)$. Harga dan fasilitas berpengaruh signifikan terhadap minat sewa dengan kontribusi pengaruh sebesar $55,5 \%$ sedangkan sisanya sebesar $44,5 \%$ dipengaruhi faktor lain. Uji hipotesis diperoleh nilai $\mathrm{F}$ hitung $>\mathrm{F}$ tabel atau $(60,568>2,699)$. Minat sewa berpengaruh signifikan terhadap prestasi belajar dengan kontribusi pengaruh sebesar $39,8 \%$. Uji hipotesis diperoleh nilai t hitung $>t$ tabel atau $(8,051>1,984)$.

\section{DAFTAR PUSTAKA}

Amilia, S, dan Iriyani (2019). Pengaruh Lokasi, Harga dan Fasilitas terhadap Keputusan Sewa Kamar Kost Mahasiswa Fakultas Ekonomi Universitas Samudra. Jurnal Manajemen Dan Keuangan, Vol 8, No 3, Desember 2019

Hastono, H. (2020). Faktor-Faktor Pendukung Prestasi Belajar Mahasiswa (Studi Pada Mahasiswa Penghuni Rumah Kost Di Lingkungan Kampus Universitas Teknologi Yogyakarta). Vol. 4 No. 3 Juni 2020

Hulu, T., Irna M., (2013), Hubungan Antara Kecerdasan Emosi dan Efikasi Diri dengan Prestasi Belajar, Analitika: 5 (2): 50-56

Kurniawan, A, (2015). Analisis Pengaruh Lokasi Dan Fasilitas Terhadap Keputusan Mahasiswa Memilih Tempat Indekos Dengan Harga Sewa Indekos Sebagai Variabel Moderasi. Jurnal Ekonomi dan Kewirausahaan Vol. 15 No 2 Juni 2015: 236 - 244

Lukiastuti, F, (2020). The Influence of Entrepreneur's Personal Characteristics on SMES Performance Mediated by Entrepreneurial Orientation. International Journal of Psychosocial Rehabilitation. Volume 24 - Issue 8

Minauli, I., Imelda B.,(2011), Hubungan Antara Efikasi Diri Dan Regulasi Diri Dalam Belajar Dengan Prestasi Akademik Mahasiswa, Analitika: 3 (2): 99-114

Rahmawati dan Hastuti, I. (2017). Hubungan Motivasi Belajar Dan Pemanfaatan Fasilitas Belajar Dengan Prestasi Belajar Mahasiswa D-Iii Kebidanan Semester Iii Di Stikes Yogyakarta T.A 2013/2014. JURNAL EDUMidwifery, Vol. 1, No. 2, September 2017

Rahmayati, T.E., Zulkarnain L., (2013), Hubungan Efikasi Diri Akademik dan Dukungan Sosial dengan Penyesuaian Diri, Analitika: 5 (2): 43-49

Setyawan, A. (2018). Analisis Faktor-Faktor Yang Mempengaruhi Kinerja Karyawan Perusahaan Fabrikasi Lepas Pantai Di Batam Dan. Journal of Accounting \& Management Innovation, Volume 2(Nomor 1), 67-89.

Sitanggang, O.E.Y., Nini S.W., (2014), Hubungan antara Efikasi Diri dengan Kecemasan pada Calon TKI, Analitika: 6 (1): 37-43

Sunarto. (2009). Pengertian Prestasi Belajar. Yogyakarta: Amus dan Citra Pustaka.

Tarigan, R.br., Sri M., Nurmaida I., (2015), Pengaruh Bimbingan Kelompok Peer Group terhadap Efikasi Diri dan Self-Regulated Learning, Analitika: 7 (2): 67-79

Wijoyo, H. (2020). Analisis Minat Belajar Mahasiswa STMIK Dharmapala Riau Dimasa Pandemi Coronavirus Disease (Covid-19). JURNAL PENDIDIKAN: RISET DAN KONSEPTUAL, 4(3), 396-404. https://doi.org/10.28926/riset_konseptual.v4i3.2

Wijoyo, H., \& Indrawan, I. (2020). Model pembelajaran menyongsong new era normal pada lembaga paud di riau. JS (Jurnal Sekolah) Universitas Negeri Medan, 4(3), 205-212. https://doi.org/https://doi.org/10.24114/js.v4i3.18526 